\section{$1 \mathrm{P} 041$}

単粒子解析における蛋白質単分子透過像間の相対才 イラー角決定法

○高橋勝利、上野豊、浅井潔（産総研・生命情報科学研究 センタ一)

電子顕微鏡による蛋白質単粒子解析は、新たな蛋白質立体構造解析技 術として近年非常に注目されている。単粒子解析をサポートするソフ トウエアが数種開発されているが、これらはウイルス粒子などの比較 的巨大な、対称性の高い粒子の解析を想定したものであり、(i) 蛋白 質単分子像抽出、(ii) 単分子像のグループ化・位置合わせ・平均化、 (iii) 単分子像間の相対オイラー角決定、を行う際に実験者の直感と試 行錯誤が必須となる。

本研究では、蛋白質のクライオ透過電子顕微鏡像から人間の介在なし に客観的に単粒子解析を行うためのコンピュータ・アルゴリズム及び 解析システムの実現を目指している。PCクラスターを利用して、平 均化処理された $n$ 個の蛋白質単分子透過像間の相対才イラー角を自 動的に決定する方法を検討した。

異なる透過像は、蛋白質の 3 次元密度分有を異なる方问（視角; オイ ラー角で表す）に射影した像であると考えられ、理想的には共通線定 理により3つ以上の異なる透過像間の相対オイラ一角を一義的に沠定 できる。しかし現実問題としては、ノイズや平均化する際のグループ 化・位置合わせ誤差の影響で、3つの簧なる透過像の相対オイラー角 ですら一義的に決定することは難しい。

ここではまず $n$ 個の透過像から3つを選ぶ全ての組み合わせに対して 共通線定理を適用して相対才イラー角を推定する。次に画像の形状相 関解析を行い、相関性の高い順に $m$ 組を選び出す。この $m$ 組の各々 に残りの $(n-3)$ 個の透過像を差して形状相関解析を行い相関の高い $m$ 組を選び出す。これを繰り返すことにより、n個の透過像の相対才 イラー角セットを $m$ 組選び出すことができる。 $n$ に比べて $m$ が充分 大きいときには妥当な解が得られることが明らかになったので報告 する。

K.Takahashi, Y. Ueno and K. Asai : Relative Eulerian angle determination in protein single particle analysis

\section{$1 \mathrm{P} 043$}

PSD-Zip45におけるHomer1 ファミリー保存領域の $\mathrm{X}$ 線結晶構造解析

○人江 克雅 1 、中津 亭 2 、光岡 薫 1 、宮澤淳夫 2 、祖父 江 憲治 ${ }^{3}$ 、廣明 洋子 1 、土井 知子- 4 、藤吉 好則 ${ }^{1,2}$ 、加藤博章 2 (1京大·院理・生物物理、2 理研・播磨・MDグループ、3 阪大·院医・神経科学、 ${ }^{4}$ 日本電子)

【目的】 PSD-Zip45 (Homer1c) は、神経伝達に主要な受容体である代 謝型グルタミン酸受容体 (mGluR) のタイプ $1 \alpha$ 型や5型の受容体と 結合する足場タンパク質である。N末側に enabled/VASP homology 1 domain (EVH1 domain)をもちこれを介して mGluR と結合する。 さらにC末端にある leucine motifで自己重合し、mGluRをシナプス 徯肥厚部 (PSD)に集積させている。この受容体結合機構を解明する ために発現系を確立し、X線結晶構造解析を行った。

【方法と結果】大腸菌を用いたGST 融合タンパク翼発現系を用いて PSD-Zip45の全長について発現拉よび精製を行った。プロテアーゼ限 定分解と質量分析により、Homer1 ファミリー内に扔いてよく保存さ れている領域である1-175残基の領域が結晶化に適していることを見 出した。この領域は EVH1 domain を含んで㧍り、この領域の結唱化 を行い、 $0.4 \mathrm{~mm} \times 0.4 \mathrm{~mm} \times 0.02 \mathrm{~mm}$ 程度の板状結晶を得た。そこで、 この結晶のX線回折実験を SPring-8のビームライン BL45XUで行い、 $1.8 \AA$ 分解能までの回折データを収集した。その結果、この絬晶は空間 群 $P 22_{1} 2$ 2、格子定数 $a=55.3 \AA, b=71.2 \AA, c=39.6 \AA$ であった。 構造解析は Homer1a の EVH1domain 部分の棈造を初期モデルに用い て、分子置換法にて行った。構透解析の結果により、EVH1domainの $\mathrm{C}$ 末側の $\alpha$-helix は既知のものより 2 回転分長いこと、それ以降の $\mathrm{C}$ 末側である 118-163 残基の領域は特定の構造をとっていないことが分 かった。これにより PSD-Zip45に扔りる EVH1 domain は 1-118残基 の領域であることが判明した。また、この結晶構造中では138-142残 基が隣接する分子の EVH1 domainの mGluR との結合サイトをふさ ぐように結合していた。

K.Irie,T.Nakatsu,K,Mitsuoka,A.Miyazawa,K.Sobue,Y.Hiroaki,T.Doi, Y.Fujiyoshi,H.Kato : Crystal structure of PSD-Zip45 conserved region of the Homer 1 family

\section{$1 \mathrm{P} 042$}

4 回膜貫通型 $\mathrm{C}$ 型肝炎ウイルスレセプターCD81の 構造と機能

○北所 健悟 ${ }^{1,2}$ 、Domenico Bordo ${ }^{2}$ 、Giuliano Galli ${ }^{3}$ 、Roberto Petracca ${ }^{3}$ 、Fabiana Falugi ${ }^{3}$ 、Sergio Abrignani ${ }^{3}$ 、Guido Grandi ${ }^{3}$ 、 Martino Bolognesi ${ }^{2}$ ( ${ }^{1}$ 京大院・理学系・機器分析セン多一、 ${ }^{2}$ ジエノバ大·ABCセンター、3カイロン・ワクチンリサーチ センター）

$\mathrm{C}$ 型肝炎は世界人口の約 $3 \%$ にあたる 1.7 億人もの人々に感染するウ イルス性の病気であり、肝瀻における主たる病気の原因となっている。 $\mathrm{C}$ 型肝炎ウイルス $(\mathrm{HCV})$ の存在は以前より知られているが、その感 染や発症のメカニズムついてはよく理解されていない。最近、HCV ウイルスのエンベロープ糖蛋白質がヒトの CD81 分子の細胞外領域 に結合することが見い出されている。CD81は、Tetraspaninファミ リーに属する細胞表面の抗原性レセプターの1つであり、種々の免 疫応答に関与する重要な役割を担っている。CD81 分子は、236 個の アミノ酸からなる 4 回膜貫通型の膜蛋白質であり、2つの細胞外領 域と 3 つの細胞内ドメイン㧍よび 4 つの膜貫通疎水性領域から形成 されている。このうち CD81の細胞外領域の 1 つである LEL(Large Extracellular Loop)ドメインは、91個のアミノ酸からなり、他の 160 種類の Tetraspainレセプターと同様に 2 つの S-S 結合を有する。我々 はヒトのCD81のウイルス結合ドメインであるLEL(CD81-LEL)のX 線構造解析を行い、この立体構造が全く新規なモチーフであること を見い出し、また CD81-LEL と HCV ウイルスとが相互作用すると 思われる部位を同定した (1)。構造解析は重原子多重同型置換法で行 い、1.6A分解能の回折データを用いて精密化を行った。その結果、 CD81-LEL は二量体で、各々のサブュニットは 5 本の $\alpha$ ーヘリックス とそれをつなぐループ部分で構成され、stalk と head サブドメインか らなる”mushroom-like”の立体構造をとっていた。HCVの結合に関与 するアミノ酸残基は、headサブドメインにある踈水性クラスターに 集中しており、これらの側鎖は外側に突出した形で存在し、結晶内で

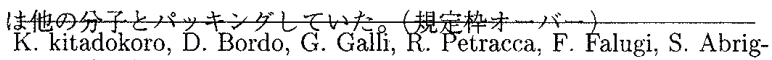
nani, G. Grandi and M. Bolognesi : Structure and function of tetraspanin receptor $\mathrm{CD} 81$ which bind to $\mathrm{HCV}$.

\section{$1 \mathrm{P044}$}

織維状ウイルス $(\mathrm{Pf1}, \mathrm{Pf3})$ のアルギニン側鎖の配向 決定に関する基礎的研究:アルギニン残基のラマンテ ンソル決定

○中村 浩二 1 、坪井正道 ${ }^{2}$ 、相田 美砂子 3 、Priya Bondre ${ }^{4}$ 、 Stacy A. Overman ${ }^{4}$ 、James M. Benevides 4 、George J. Thomas, $\mathrm{Jr}^{4}$ ( ${ }^{1}$ 岐皁医療技術短大・衛生技術、2いわき明星大・理工、

${ }^{3}$ 広島大学、 ${ }^{4}$ University of Missouri-Kansas City)

瀻維状ウイルス (Pf1，Pf3)は，そのコートタンパク質に，それぞれ1 個のアルギニン残基を含んでいる。Pf1，Pf3のラマンバンドに対す るアルギニン側鎖の㷌属が決定できれば，その異方性を求め，偏光影 微ラマン分光法を応用して，その配向を決定する事ができると考えら れる。今回我々は，そのラマンバンドの帰属決定のため, 基礎的な研 究を行った。アルギニン側鎖の慢属決定のため, Methyl guanidine · $\mathrm{HCl}, \mathrm{L}$-arginine $\cdot \mathrm{HCl}$, L-arginine $\cdot \mathrm{HCl}^{-15} \mathrm{~N}_{2}$, Poly-L-arginine の固 体そして軽水㧍よび重水溶液を，可視㧍よび近赤外ラマン分光法で測 定を行った。また $A b$ initio SCF MO 法を用いて, Methyl guanidine 分子の振動計算をおこなった。このラマン測定拉よび計算の結果加 ら，いくつか考吕れるアルギニン残基のラマンテンソルとして, 特 に $1083 \mathrm{~cm}^{-1}$ での平面骨格伸縮振動が，偏光ラマン顕微鏡によるア ルギニン側鎖の配向決定に有用であることを示した。この方法は Pf1 やPf3に扔りコートタンパク質の，アルギニン残基配向決定に有用 であった。
K.Nakamura, M.Tsuboi, M.Aida, P.Bondre, S.A.Overman, J.M.Benevides and G.J.Thomas,Jr. : A basis for determining orientations of arginine side chains in filamentouse viruses (Pf1 and Pf3) by polarized Raman spectroscopy. 